\title{
The Impact of Strategic Notetaking on EFL learners' Academic Performance in Jordan
}

\author{
Dr. Ibrahim F. F. Almaagbh ${ }^{1}$ \\ ${ }^{1}$ Department of English Language, Literature and Translation, Zarqa University, Zarqa, Jordan \\ Correspondence: Dr. Ibrahim F. F. Almaagbh, Department of English Language, Literature and Translation, Zarqa \\ University, Zarqa, Jordan.
}

This research is funded by the Deanship of Scientific Research at Zarqa University-Jordan

Received: September 2, 2019

Accepted: February 4, 2020

Online Published: February 6, 2020

doi:10.5430/ijhe.v9n 1p249

URL: https://doi.org/10.5430/ijhe.v9n1p249

\begin{abstract}
This study investigates the impact of strategic notetaking on English as Foreign Language (EFL) learners' academic performance among university students in Jordan. Thus, we hypothesized that there is a significant and positive impact of strategic note-taking on EFL learners' academic performance. To confirm this hypothesis, descriptive research design was applied in this study. 384 (three hundred and eighty-four) respondents were randomly selected from the four public universities in Jordan. This study adapted instruments which include strategic note taking and students' academic performance measurement items and the data obtained was analysed through Statistical Package for the Social Science (SPSS-22). The result showed that the strategic note taking (i.e. independent variable) has significant effects on EFL learners' academic performance $(\mathrm{R} 2=.919)$. Moreover, the strategic notetaking made the significant contribution $(B e t a=.449 ; \mathrm{t}=18.714 ; \mathrm{P}<0.05)$ to the prediction of EFL learners' academic performance. In line with the findings, this study emphasised and explained the impact of strategic notetaking and how to improve EFL learners' level of notetaking for better academic performance in Jordan.
\end{abstract}

Keywords: strategic Note-taking, English as Foreign Language (EFL), academic performance, Statistical Package for the Social Science (SPSS), Jordan

\section{Introduction}

The pattern of class lecture in the university level is different than the school level and thus, students must depend on themselves in growing and implementing personal skills and strategies (Harrouz, 2016). According to Simbo (2015), and Davis \&Hult (2007) learners have to implement note-taking strategy at the university level for the better academic performance (Bonner \& Holliday, 2006; Teng, 1996; Ayer \& Milson, 1993). However, most EFL learners have limited awareness about the significance of strategic note-taking and how much it can improve their academic performance (Harrouz, 2016, Kobayashi, 2009). In fact, limited students recognize how fast memory tail off; studies on memory exposed that without brush up, $47 \%$ of what a person has just learned is failed to recall in the first twenty minutes and after the first day $62 \%$ is forgotten (Senkowski, 2016). Since EFL learners' academic performance is strongly linked to note-taking, hence, strategic note-taking adaptation is extremely important (Harrouz, 2016; Senkowski, 2016). Consequently, note-taking is an allied strategy that lecturers should advice to adopt for boosting their students' academic performance. Therefore, effective lecture note-taking and their brush up can conclude how good EFL learners are able to improve their academic performance (Simbo, 2015).

\section{Background}

EFL learners' academic performance of students in Jordan has been of much trepidation to one and all. Likewise, Aremu\&Sokan (2017), point up that academic performance has turn out to be a key issue of importance to the students, parents, teachers, educational psychologists, psychometricians, academic researchers, and policy makers in Jordanian education arena. According to Muraina, Muraina, Amao, \&Oyelade (2015), past literature has shown that academic performance of EFL leaners has been depended on verbal instruction of lecturer to employ particular strategy (Jonassen, 2014); pre-training in reviewing skills (Stahl, King, \&Henk, 2011); verbal instructions to employ a particular strategy (Davis \&Hult, 2007); and complementing personal with instructors' notes for the period of later brush up (Kiewra, 2015). Moreover, Parker and Wool (2017), claimed that most of the past studies have concentrated 
on the influence of socio-psychological and demographic variables on academic performance in Jordan (Aremu\&Sokan, 2017; Aremu, 2015) but they did not enough focus on the impact of strategic note-taking skill for better academic performance (Robin et al., 2014). Despite of the apparent extensive past studies on the determining factor of academic performance of EFL learners, there give the impression to be more issue to be explored. This come to be deceptive bearing in mind the endure interest of Jordanian researchers and educational psychologists; academic policy makers and the persistent attention of Jordanian government.

\section{Statement of the Problem}

Due to poor academic performance of EFL learners especially among the public university students in Jordan, numerous educationists have a habit of charging the teaching methodology adopted by the lecturers and explaining the lack of fund from the government to provide quality textbooks. Nevertheless, these might not be the foremost reasons why students not performing well. Consequently, numerous EFL learners argue that, when they attend in their class for class lecture, they can go along straightforwardly, but some-time later, when the issue comes to recall about what it has been said, they solely cannot. Another problem that students address is, the swift desertion of the content of what they taught and communicated in their class. Several students try to get down the lecturer's word exactly but they cannot do it. Likewise, others fail to take even the simplest notes. Hence, students like the class notes when teachers provide it, because those class notes ease them to recall the class lecture. Therefore, in both circumstances, students could improve their academic performance by giving more attention to the strategic note-taking. However, it is yet to gather adequate research evidence to prove that strategic notetaking is a vital factor of EFL learners' better academic performance in Jordan. Consequently, this study investigates the impact of strategic note-taking on EFL learners' academic performance.

\section{Literature Review}

Competence of taking notes is one of the most effective strategies that students have to adopt at university level (Harrouz, 2016; Simbo, 2015). According to prior researches, appropriate strategy of note-taking will help the students not only to recall academic topics and materials, but also to boost their overall academic performance (Robin et al., 2014). Moreover, World Bank (2016) indicated that effective progress entails more than devoting in physical capital, or minimizing the gap in capital and which entails gaining and utilizing knowledge as well as closing the gaps in knowledge. Hence, knowledge and skill possession which is known as education is vital for a nation to establish and sustained as a developed nation. Consequently, Alghieri (1948), stated that academic performance of a student depends on note-taking ability in the class and recently Leyson et al. (2016) claimed that meaningful note-taking helps to boost academic performance of EFL learners. Actually, academic performance of EFL learners at university level in Jordan is suffering due to poor habit of coping lecture notes from others and to abortive note taking skills as well as inappropriate study habit.

Harrouz (2016), mentioned that note-taking has been an indispensable action of academic life, predominantly for EFL learners. Muaina et al. (2015), and Hale \& Courtney (2012), recognized that note-taking could help students ability to remember the content straightforwardly. The determination of their study was to open up whether note-taking could uphold EFL students' academic performance, and found that $77 \%$ of students can remember the content straightforwardly by taking notes which helps to get better performance of the students. Moreover, Huang (2014), specified that the problems with note-taking as well as lack of note-taking ability are problematic issues maximum time narrated by university students.

Consequently, researches on notetaking point out that taking notes in class and reviewing those notes have a positive impact on students' academic performance. Hence, according to Spires (2011), notetaking should be a key segment of the curriculum and Liu (2015) explained that notetaking is a useful strategy for students to progress their listening comprehension. Expectedly, the majority of studies endorses that students' ability to remember extra lecture material if they write it in their notebooks (Leyson et al., 2016). Muraina et al. (2015), and Senkowski (2016), language teachers have considered notetaking from different perceptions. Several researchers have found significant effect of notetaking on learning performance. According to Hale \& Courtney (2017) out of thirty-five studies on the impacts of note-taking, seventeen past studies obtained that the note takers done better than the non-note takers, sixteen studies establish no difference, two studies realised that note-taking affected performance and remaining studies specify that note-taking has no effect on the learners' performance.

Moreover, Kiewra, Benton, and Lewis (2014), claimed that students who took notes score higher than the students who do not take notes on both immediate and delayed tests. Additionally, he claimed that undergraduates who did not attend at the lecture but collected notes from other students did better performance than students who did not review notes. However, several reports indicate that students fail to record $40 \%$ of the central discussion as class note 
due to higher rate of verbal communication than material written on the blackboard during the class lecture (Howe, 2017; Muraina et al., 2015). To sum up, note taking facilitates and significantly improve recall of lecture material of EFL learners which is directly help to improve students' academic performance.

Numerous studies have been accomplished which are presented today an important record on strategic note-taking (Ogunmakin, 2011; Gbore, 2006, Kumar, 2002;). The researchers claimed that strategic notetaking has convincing association with academic performance of students while some other academics (Muraina, 2013; Owolabi, 2006) established that it was the amalgamation of the strategic note-taking and other issues that could clarify students' academic performance in any course of study. Basically, with the intention of filling the gaps in the mentioned studies, the present study anticipates to find out the impact of strategic note taking on EFL learners' academic performance among public university students in Jordan. Thus, this study proposes the following hypothesis:

H1: There is a significant and positive impact of strategic note-taking on EFL learners' academic performance in Jordan.

\section{Methodology}

\subsection{Research Design}

Descriptive study is used as the research design in this study. This study is working to determine the impact of strategic notetaking (i.e. independent variable) on EFL learners' academic performance (i.e. dependent variable). Nevertheless, it is cautiously scrutinised and documented data as it genuinely arose during the study was accomplished.

\subsection{Population, Sample and Sampling Techniques}

The students studying in public university in Jordan are considered as the population of this study. In this regard, a structured survey was conducted and the sample size of this study includes 384 respondents which were randomly selected from four public universities in Jordan (i.e. University of Jordan in Amman, Jordan university of Science and Technology in Irbid, The Hashemite University in Zarqa, and Al-Balqa' Applied University in Ajloun). Overall, three hundred and eighty-four university students were picked for this study.

\subsection{Instrument}

For strategic notetaking construct, this study adapted and customized fifteen items from the notetaking scales developed by Patricia (2007) as well as employed as a measure of notetaking Questionnaire. Whereas, from the work of Bennett, Power, Eiraldi, Leff, and Blum (2009), this this study adapted and customized ten (10) items for measuring academic performance of EFL leaner. This study used five-point interval scale with one (1) representing to strongly disagree and five (5) as strongly agree for all two constructs.

\subsection{Validity and Reliability of Instrument}

For the validity of the instrument is given to experts in the field of research and statistics as well as educational psychology. Particularly, all these experts had made essential corrections on the instrument and gave some specific suggestions. Whereas, after completing content \& face validity of the measure tool, twenty-five (25) copies of the instruments were processed with the intention of testing reliability. The Cronbach's alpha was then being exercised to test their reliability to make sure that they are reliable in evaluating what they were designed to measure. The reliability coefficient of .77 was obtained.

\section{Results}

Table 1. Descriptive statistics and Correlations among the variables

\begin{tabular}{cccccc}
\hline Variables & $N$ & Mean & SD & $\begin{array}{c}\text { Academic } \\
\text { Performance }\end{array}$ & $\begin{array}{c}\text { Strategic } \\
\text { Notetaking }\end{array}$ \\
\hline Academic Performance & 384 & 32.47 & 23.69 & 1.00 & \\
Academic Performance & 384 & 35.41 & 17.96 & .574 & 1.00
\end{tabular}

Table 1 showed the descriptive statistics and correlations among the independent and dependent variables. As shown in above table 1, EFL learners' academic performance is significantly correlated with notetaking $(r=.574 ; \mathrm{p}<0.05)$. 
Table 2. Regression analysis on students' Academic performance

\begin{tabular}{ccccc}
\hline \multicolumn{5}{c}{$\mathrm{R}$ (adjusted) $=.952$} \\
$\mathrm{R}^{2}$ (adjusted) $=.919$ \\
$\mathrm{~S}_{\mathrm{E}}=5.879$
\end{tabular}

The table above shows that the independent variable strategic notetaking after pulled together has significant impact on the EFL learners' academic performance. The value of $\mathrm{R}$ (adjusted) =.952 and R2 (adjusted) $=.919$. The analysis of variance performed on the multiple regressions yielded a F- ratio value of 763.29 and was found to be significant at 0.05 level.

Table 3. Relative contribution of independent variables to the prediction

\begin{tabular}{cccccc}
\hline & $\begin{array}{c}\text { Unstandardized } \\
\text { coefficients }\end{array}$ & \multicolumn{2}{c}{$\begin{array}{c}\text { Standardized } \\
\text { coefficients }\end{array}$} & & \\
\hline Model & $B$ & $\begin{array}{c}\text { Standard } \\
\text { error }\end{array}$ & Beta & $T$ & $P$ \\
\hline Constant & 19.469 & 1.579 & & 12.330 & $\mathrm{P}<0.05$ \\
Strategic Notetaking & .655 & .035 & .449 & 18.714 &
\end{tabular}

The above table shows that the Strategic Notetaking made a significant contribution to the prediction of EFL learners' academic performance. In the magnitude of contribution, strategic notetaking made the most significant contribution (Beta $=.449 ; \mathrm{t}=18.714 ; \mathrm{P}<0.05)$.

\section{Discussion of Findings}

The result of this study showed, there was a significant relationship between the independent variable (strategic notetaking) and the dependent variables (EFL learners' academic performance). This result is consistent with the study of Kiewra (2015), strategic notetaking is useful as strategic notetaking helps to learn by stimulating attention and joining learner's cognitive processes of integrating, coding, synthesizing, and transforming obtained input into an evocative form. Moreover, notetaking is perceived as useful as it assists as a peripheral source of information that allows further revision and brush up to stimulate recall of the information heard. Students who practice proper reading skills having notetaking and studying that notes, can carry on knowledge for long time (Chaudron, Cook, \&Loschky, 2016). Consequently, this study finding determined that strategic notetaking defines to great extent students' academic performance.

The result of this study also revealed that the independent variable (strategic notetaking) has a strong positive impact on EFL learners' academic performance (i.e. dependent variable). The degree of the prediction of the independent variable was reflected in value of $\mathrm{R}$ (adjusted) $=.952$ and $\mathrm{R}^{2}$ (adjusted) $=.919$. The result so revealed that $91.9 \%$ of the variance in the EFL learners' academic performance is explained by the independent variable (i.e. strategic notetaking) of this study. The outcome is more supported by the value of F-ratio $(\mathrm{F}=763.29, \mathrm{p}<0.05)$. Thus the results are revealing is that the ability of the independent variable to predict EFL learners' academic performance could not have occurred coincidentally. This finding of this study is similar with many previous researchers' work (Chaudron et al., 2016; Bretzing, 2015; Oguz, 2014; Austin \&Carr, 2013; Bilbow, 2009; Dunkel\& Davy, 2009; Dunkel, 2008; Liu, 2005; Faraco, Barbier, \&Piolat, 2002).

The result of this study lastly reviled that the strategic notetaking has a significant positive impact on EFL learners' academic performance. That is strategic notetaking (IV) predicts the EFL learners' academic performance (DV). In the level of contribution, strategic notetaking made the most significant contribution (Beta $=.449 ; \mathrm{t}=18.714 ; \mathrm{P}<0.05$ ) to the prediction. The outcome of this study is similar with the work of many previous researchers (Armel\&Shrock, 
2016; Cohn, Cohn, \&Bradley, 2015; Fisher \& Harris, 2013; Barnett, Divesta, \&Rogozinski, 2011; Kiewra, Mayer, Christensen, Kim, \&Risch, 2011; Kiewra, 2009).

\section{Conclusion}

Grounded on the outcomes of this study, EFL learners in Jordan need to be serious to regarding strategic notetaking for changing the academic performance as this study discovered that students' strategic notetaking approach impact significantly their academic performance at the university level. Per se, it is very decisive to adopt this factor so as to remove the persistent occurrence of poor report of students' academic performance in Jordan. Specifically, it was also concluded from this study that strategic notetaking will definitely have a strong effect on students' productivity. Therefore, this strategic notetaking approach is to adopt in student life to boost academic success not only in Jordan but also all over the world and this situation is endorsed that lecturers and parents should inspire the students to inculcate positive attitudes towards strategic notetaking approach. Also, the university administrators should instruct their students on the way of improving notetaking ability in and outside the university.

\section{References}

Alighieri, D. (1948). The divine comedy: The Inferno, Purgatorio, and Paradiso. New York: Pantheon Books.

Aremu, A.O. (2015). Gender and birth order as predictors of normal pupil's anxiety pattern in examination. Ibadan Journal of Educational Studies, 1(1), 1-7.

Austin, D., Lee, O. \& Carr, K. (2013). Self-efficacy expectancies versus outcome expectancies as determinants of performance deficits and depressive affect. Cognitive Therapy and Research, 6, 23-35. https://doi.org/10.1007/BF01185724

Ayer, W. W. \& Milson, J. L. (1993). The effect of notetaking and underlining on achievement in middle school life science. Journal of Instructional Psychology, 20(2).

Barnett, F., Divesta, J. \& Rogozinski, N. (2011). Students' resistance in the classroom. Anthropology \& Education Quarterly, 22(4), 350-366. https://doi.org/10.1525/aeq.1991.22.4.05x1193w

Bennett, A.E., Power, TJ., Eiraldi, R.B., Leff, S.S \& Blum, N.J. (2009). Identifying Learning Problems in Children Evaluated for ADHD: The Academic Performance Questionnaire. Pediatrics, 124(4), e633-e639. https://doi.org/10.1542/peds.2009-0143

Bilbow, H. (2009). Assessing Individual Needs: A Practical Approach, London: David Fulton Publishers.

Bonner, J. M. \& Holliday, W. G. (2006). How College Science Students Engage in Note-Taking Strategies. Journal of Research in Science Teaching, 43(8), 786-818. https://doi.org/10.1002/tea.20115

Bretzing, G.F. (2015). The effectiveness of staff development training practices: A meta-analysis. Unpublished doctoral dissertation, University of Oregon, Eugene.

Carrell, P.L. (2007). Notetaking Strategies and Their Relationship to Performance on Listening Comprehension and Communicative Assessment Tasks. Southern Illinois University, Carbondale. https://doi.org/10.1002/j.2333-8504.2007.tb02043.x

Chaudron, V., Cook, K. \& Loschky, P. (2016). Parent involvement private schools. Retrieved from www.google.com. 19/11/18.

Cohn, F, Cohn, K. \& Bradley, L. (2015). Linking parent involvement with student achievement: Do race and income matter? The Journal of Educational Research, 93, 1-30.

Davis, M. \& Hult, R. E. (2007). Effects of Writing Summaries as a Generative Learning Activity During Note-Taking. Teaching of Psychology, 24(1), $47-49$ https://doi.org/10.1177/009862839702400112

Dunkel, A. \& Davy, B. (2009). Teachers' and children's ability to learn literacy skills. Washington, DC: National Institute for Literacy.

Dunkel, J.N. (2008). Relationship among laboratory instruction, attitude toward science and achievement in science knowledge. Journal of Research in Science Teaching, 34, 343-357. https://doi.org/10.1002/(SICI)1098-2736(199704)34:4\%3C343::AID-TEA5\%3E3.0.CO;2-R

Faraco, G., Barbier, N. \& Piolat, L. (2002). Responsibility for student learning and academic efficacy. Retrieved From http://www.google.com. 19/11/18. 
Fisher, T., \& Harris, G. (2013). Promoting Parental Involvement, Improving Student Outcomes. A working paper prepared for San Diego Dialogue. http://www.sandiegodialogue.org/pdfs/parentalinvolvement.doc.pdf

Gbore, S.K. (2006). Parental involvement: Definitions and outcomes. Social Psychology of Education, 1, 189-209. https://doi.org/10.1007/BF02339890

Harrouz, B. (2016). The Impact of the Strategic Notetaking in Enhancing EFL Learners' Listening Skill a Case Study of Third Year LMD EFL Students. BiskraUniversity.

Hayati, A.M. \& Jalilifar, A. (2009). The Impact of Note-taking Strategies on Listening Comprehension of EFL Learners. English Language Teaching, 2(1), 101-111. https://doi.org/10.5539/elt.v2n1p101

Howe, G.I. (2017). A multivariate examination of parent involvement and the social and academic competences of urban kindergarten children. Psychology in the Schools, 41, 363-373.

Huang, J. (2014). The Effects of Academic Skills on Chinese ESL Students' Lecture. Comprehension College Student Journal, 40(2), 385-392.

Jonassen, D. H. (2014). Effects of generative text processing strategies on recall and retention. Human Learning, 3, 241-256.

Kiewra, A.Z. (2009). The classroom social environment and changes in adolescents' motivation and engagement during middle school. American Educational Running head: Research Journal, 38, 437-460. https://doi.org/10.3102/00028312038002437

Kiewra, G., Benton, J. \& Lewis, P. (2014). Teacher efficacy: A construct validation. Journal of Educational Psychology, 76, 569-582. https://doi.org/10.1037/0022-0663.76.4.569

Kiewra, G., Mayer, Y., Christensen, L., Kim, S. \& Risch, R. (2011). The economics of student time. Economics of Education Review, 6(4), 357-364. https://doi.org/10.1016/0272-7757(87)90019-7

Kiewra, K.A. (2015). Notetaking and review: The research and its implications. Instructional Science, 16(3), 233-249. https://doi.org/10.1007/BF00120252

Kobayashi, K. (2009). Combined Effects of Note-Taking/-Reviewing on Learning and the Enhancement through Interventions: A meta-analytic review. Educational Psychology Review, 26(3), 459-477. https://doi.org/10.1080/01443410500342070

Kumar, F.K. (2002). An empirical study of lecture notetaking among college students. The Journal of Educational Research, 77, 93-99.

Lee, P., Lan, W., Hamman, D. \& Hendricks, B. (2008). The effects of teaching notetaking strategies on elementary students' science learning. Instructional Science, 36(3), 191-201. https://doi.org/10.1007/s11251-007-9027-4

Leyson, L., Harran, M. J., Leyson, E. B., Burstein, D., \&OverDrive Inc. (2016). The boy on the wooden box: How the impossible became possible-- on Schindler's list (Unabridged.). New York: Simon \& Schuster Audio.

Liu, H.C. (2015). Comparison of self-questioning, summarizing, and notetaking-review as strategies for learning from lectures. American Educational Research Journal, 29(2), 303-323. https://doi.org/10.3102/00028312029002303

Liu, Z. (2005). Reading Behaviour in the digital environment: changes in Reading behavior over the past 10 years. Journal of Documentation, 61(6), 700-12. https://doi.org/10.1108/00220410510632040

Muraina, K.O, Muraina, M.B, Amao, O.Z.K \& Oyelade O. (2015). Parental Educational Background and Socioeconomic Status as Factors enhancing Students Performance in Itesiwaju Local Government Area of Oyo State, Nigeria. Journal of Education, 2(1), 97-110.

Muraina, K.O. (2013). Influence of some psychological factors on the learning gains of secondary school students in Mathematics in Itesiwaju Local Government Area of Oyo State. Unpublished Med thesis, University of Ibadan, Ibadan, Nigeria.

Muraina, K.O., Muraina, M.B., Amao, O.Z.K. \& Oyelade O. (2013). Parental Educational Background and Socioeconomic Status as Factors enhancing Students Performance in Itesiwaju Local Government Area of Oyo State, Nigeria. Journal of Education, University of Uyo, Uyo, Akwalbom State. 
Muraina, M.M., Nyorere, I.O., Emana, I.E. \& Muraina, K.O. (2014). Impact of Notetaking and Study Habit on Academic Performance Among Selected Secondary School Students in Ibadan, Oyo State, Nigeria. International Journal of Education and Research, 2(6), 437-448.

Ogunmakin, A.O. (2011). The Effects of Study Habits and Academic Achievement in Mathematics Educational Thought. International Journal of Education and Research, 1(2), 167-175.

Oguz, N.O (2014). Notetaking and note review: Why students fail questions based on lecture material. Teaching of Psychology, 7(3), 159-161. https://doi.org/10.1207/s15328023top0703_8

Owolabi, G.O (2006). Visual argument: Graphic organizers are superior to outlines in improving learning from text. Journal of Educational Psychology, 87(3), 455-467. https://doi.org/10.1037/0022-0663.87.3.455

Parker, G. \& Wool, I. (2017). Effects of note taking technique and working-memory span on cognitive effort. In G. Rijlaarsdam (Series Ed.), Studies in Writing, \& D. Galbraith, M. Torrance, \& L. van Waes (Vol. Eds.), Recent developments in writing process research (Vol.1: Basic processes and word-level effects). Dordrecht: Kluwer Academic Publishers.

Patricia L.C. (2007). Notetaking Strategies and Their Relationship to Performance on Listening Comprehension and Communicative Assessment Tasks. Southern Illinois University, Carbondale. https://doi.org/10.1002/j.2333-8504.2007.tb02043.x

Robin, A. L., Foxx, R. M., Martello, J. \& Archable, C. (2014). Teaching note-taking skills to underachieving college students. Journal of Educational Research, 71, 81-85. https://doi.org/10.1080/00220671.1977.10885042

Senkowski, AJ. (2016). The Effects of a Structured Notetaking Strategy in Virtual School Mathematics. Montana State University, Bozeman, MT.

Simbo, F.K. (2015). The Effects of Notetaking Approaches on Student Achievement. The Journal of Educational Research, 81(6), 377-381. https://doi.org/10.1080/00220671.1988.10885853

Spires, H. A. (2011). Learning from a lecture: Effects of comprehension monitoring. Reading Research and Instruction, 32, 19-30. https://doi.org/10.1080/19388079309558113

Teng, H. C. (1996). The influence of note-taking on EFL lecture comprehension. Journal of Yunlin Institute of Technology, 5, 165-168.

Tsai, T. (2009). EFL College Freshman Note-Taking Training for Reading Comprehension. The Journal of Human Resource and Adult Learning, 5(2), 12-18. 